\title{
Breastfeeding and protection against diarrhea: an integrative review of literature
}

\author{
Aleitamento materno e proteção contra diarreia: revisão integrativa da literatura
}

\author{
Floriacy Stabnow Santos ${ }^{1}$, Felipe César Stabnow Santos ${ }^{2}$, Leonardo Hunaldo dos Santos ${ }^{3}$, \\ Adriana Moraes Leite ${ }^{1}$, Débora Falleiros de Mello ${ }^{1}$
}

\begin{abstract}
Objective: To identify, in national and international journals, the studies conducted in Brazil related to breast feeding and reducing cases of diarrhea in children under 2 years of age, featuring health interventions more used. Methods: Descriptive study, based on an integrative review of literature from PubMed and LILACS data published between January 1992 and August 2011. The keywords "breastfeeding AND diarrhea" was searched in Portuguese, English and Spanish in PubMed and LILACS. The guiding question was: "What was knowledge produced about breast feeding and prevention of diarrhea in children under 2 years between 1992 and 2011 in studies conducted in Brazil?" Results: We selected 11 studies that showed the importance of breast feeding in the prevention and protection against diarrhea in children under 6 months, especially among children in exclusive breastfeeding. Conclusion: Public health policies should be directed to the context of each locality, in order to reduce the problems that involve the early weaning.
\end{abstract}

Keywords: Breast feeding; Diarrhea; Child nutrition

\section{RESUMO}

Objetivo: Identificar, em revistas científicas nacionais e internacionais os estudos realizados no Brasil sobre 0 aleitamento materno e sua relação com a redução de casos de diarreia em crianças com menos de 2 anos de idade, e que apresentam as intervenções de saúde mais utilizadas. Métodos: Estudo descritivo, baseado em revisão integrativa da literatura, a partir de dados do LILACS e do PubMed, publicados no período de janeiro de 1992 a agosto de 2011. 0 termo "aleitamento materno $\mathrm{E}$ diarreia" foi pesquisado nessas bases de dados em português, inglês e espanhol. A pergunta norteadora foi: "Qual o conhecimento produzido sobre aleitamento materno e prevenção de diarreia em crianças menores de 2 anos entre 1992 e 2011 em estudos realizados no Brasil?". Resultados: Foram selecionados 11 artigos, que evidenciaram a importância do aleitamento materno na prevenção e na proteção contra a diarreia nos menores de 6 meses, especialmente nas crianças em aleitamento exclusivo. Conclusão: Os estudos analisados evidenciam o aleitamento materno como um fator de importância na prevenção e na proteção contra a diarreia nos menores de 2 anos. Os resultados sugerem que essa prática é importante para reduzir a mortalidade pós-neonatal bem como a taxa de internação hospitalar por doenças diarreicas na população infantil.

Descritores: Aleitamento materno; Diarreia; Nutrição da criança

\section{INTRODUCTION}

Protecting, promoting and supporting breastfeeding have been relevant strategies in the global efforts to improve health conditions of children. The benefits of breastfeeding translate into lower rates of diarrhea, of respiratory tract infections and other infections, as well as lower mortality from these diseases in breastfed infants as compared to non-breastfed infants. ${ }^{(1,2)}$

A study conducted by the Ministry of Health concluded that the prevalence of breastfeeding until the second month of life was $85.7 \%$, showing a very positive situation. ${ }^{(3)}$ However, the early introduction of complementary foods, in addition to teas, water and other types of milk, contributes to the emergence of infectious diseases, including diarrhea. ${ }^{(4)}$

A consolidated evidence in the scientific literature of health care is the importance of exclusive breastfeeding for children survival, growth and development, especially in developing countries. ${ }^{(5)}$

\footnotetext{
Escola de Enfermagem de Ribeirão Preto, Universidade de São Paulo, Ribeirão Preto, SP, Brazil.

2 Hospital Universitário de Brasília, Brasília, DF, Brazil.

${ }^{3}$ Universidade Federal do Maranhão, Imperatriz, MA, Brazil.

Corresponding author: Floriacy Stabnow Santos - Rua Urbano Santos, s/n -Centro - Zipe cod:65901-490 - Imperatriz, MA, Brazil - Phone:(55 99) 3529-6007 - E-mail: floriacys@usp.br

Received on: Mar 13, 2014 - Accepted on: Aug 29, 2014

DOI: 10.1590/S1679-45082015RW3107
} 
The World Health Organization (WHO) recommends breast milk to be the only baby food during the first six months of life, and its use is recommended until the age of 24 months or longer, but in combination with other foods. ${ }^{(6)}$

Diarrhea is considered a serious public health problem and is the second cause of child hospitalization surpassed only by respiratory infections, which are considered the leading cause of infant mortality. ${ }^{(7)}$ Between 2000 and 2010, a total of 29,491,078 cases of acute diarrheal diseases were reported in Brazil. Only the in the North Region, in 2006, there were 33 cases per 1,000 live births, and in 2009, in the Southeast Region, the incidence was 15 cases per 1,000 live births. ${ }^{(8)}$

However, the situation may be even worse, since there isunderreporting and the current statistics do not portray an accurate picture of diarrhea in many places. ${ }^{(9)}$ Therefore, it is relevant to broaden discussions on the importance of breastfeeding in the prevention of diarrheal diseases.

\section{OBJECTIVE}

To characterize health interventions on breastfeeding and their relation with reduced number of cases of diarrhea in children under 2 years of age, highlighting the most used health measures.

\section{METHODS}

This was a retrospective, descriptive study that followed the steps of an integrative review of published studies to obtain conclusions about breastfeeding and the reduction of diarrhea in children under 2 years of age.

The following steps were made: (1) identification of the problem and definition of the study's guiding question; (2) definition of the inclusion and exclusion criteria for articles; (3) categorization of the studies; (4) analysis of the selected studies in an integrative review; (5) data analysis and interpretation of results; and (6) knowledge synthesis.

We consulted the manuals of the Ministry of Health and articles that addressed the subject, and those became the theoretical framework of the study.

The guiding question defined for this study was: "What is the knowledge produced about breastfeeding and the prevention of diarrhea in children under 2 years of age, in studies conducted in Brazil, in the period between 1992 and 2011?"

The following inclusion criteria were used to make the sample: complete articles published from 1992 to
August 2011, in Portuguese, English or Spanish; studies performed in Brazil; with children up to 2 years. Literature searches, literature reviews, monographs, dissertations and theses, and studies with children aged over 2 years were excluded.

In the methodological sequence, the literature review was performed using the LILACS and PubMed databases. The publications were selected from the descriptors: "aleitamento materno AND diarreia" in Portuguese; "breast feeding AND diarrhea" in English; and "la lactancia materna AND diarrea" in Spanish. The literature search was conducted in January 2012, through online research.

In LILACS, we found 128 references, of which 10 were included in PubMed, we found 116 references, but only one met the search criteria and contained answers to the defined guiding question. The selected studies show methodological rigor and sample compatible with quality and unbiased studies (Chart 1).

Chart 1. Analysis of references according to type of study and sample

\begin{tabular}{|c|c|}
\hline Type of study & Sample \\
\hline Case-control|10\} & 448 cases of hospital deaths \\
\hline Prospective cohort ${ }^{(11)}$ & 91 children aged zero to 6 months \\
\hline Case-contro| $\left.\right|^{12\rangle}$ & 576 children aged zero to 23 months \\
\hline Cohort ${ }^{(13)}$ & 605 mothers and children \\
\hline Cross-sectional $^{(14)}$ & 14 municipalities \\
\hline Cross-sectional|(15) & 2,323 mothers of children under 1 year \\
\hline $\begin{array}{l}\text { Cross-sectional study nested in a } \\
\text { case-control study }{ }^{(16)}\end{array}$ & 273 children under 2 years \\
\hline Case-contro| ${ }^{|17\rangle}$ & 354 newborn children \\
\hline $\begin{array}{l}\text { Descriptive, retrospective and } \\
\text { uncontrolled }\end{array}$ & 71 children under 6 months \\
\hline Ecological analytical epidemiological ${ }^{(19)}$ & 598,235 children under 1 year \\
\hline Randomized field trial clusters ${ }^{(20)}$ & 619 children under 1 year \\
\hline
\end{tabular}

After defining the information to be extracted from the identified studies, the selected articles were read and analyzed in full; then, the results were interpreted and knowledge was synthesized, with a discussion of the evidence found. The data were analyzed and the results were displayed in charts for the evaluation and subsequent synthesis of the articles that met the inclusion criteria.

\section{RESULTS}

A total of 11 articles were selected to compose this integrative review, as shown in chart 2 . 
Chart 2. Analysis of references according to year, language, and database

\begin{tabular}{|c|c|c|}
\hline Reference & Language & Database \\
\hline Post et al..$^{(10)}$ & Portuguese & LILACS \\
\hline Bittencourt et al. ${ }^{(11)}$ & Portuguese & LILACS \\
\hline Fuchs and Victoria ${ }^{\mid 12\}}$ & English & LILACS \\
\hline Barros et al. ${ }^{(13)}$ & Portuguese & LILACS \\
\hline Escuder et al..144) & Portuguese & LILACS \\
\hline Vieira et al..$^{(15)}$ & Portuguese & LILACS \\
\hline Vanderlei and Silva ${ }^{(16)}$ & Portuguese & LILACS \\
\hline Vitolo et al.(17) & Portuguese & LILACS and PubMed \\
\hline Brandão et al..(18) & Portuguese & LILACS \\
\hline Boccolini and Boccollini(19) & Portuguese & LILACS \\
\hline Bernardi et al. ${ }^{(20)}$ & Portuguese & LILACS \\
\hline
\end{tabular}

Among the articles on child diarrhea and breastfeeding published from 1992 to 2011, four (36.2\%) studies were published in the Caderno de Saúde Pública, two (18.1\%) in the Revista Saúde Pública and in the Revista da Associação Médica Brasileira, and one $(9.2 \%)$ in the Revista Brasileira de Epidemiologia, in the
Jornal de Pediatria and in the Revista de Epidemiologia e Serviços de Saúde.

The articles were analyzed in full, as shown in the chart 3, in accordance with the objectives and results presented. The research showed that infant mortality was associated with prematurity, low birth weight, poor general condition, deficit in weight and height for age, lack of breastfeeding, ${ }^{(10,12)}$ adverse socioeconomic factors (such as lack of sanitation), ${ }^{(15)}$ and low maternal levels.(16) Diarrhea was mainly associated with socioeconomic/demographic factors in the population.

The studies also showed that health interventions, such as guidelines offered to mothers during consultations at lactation centers ${ }^{(13)}$ and updates on healthy feeding, ${ }^{(17)}$ were considered effective in the maintenance of exclusive breastfeeding and breastfeeding, and consequently in reducing diarrhea. Identifying diarrhea early is very important, as well as encouraging, supporting and protecting breastfeeding, with educational interventions concerning nutritional status and healthy eating habits. ${ }^{(10-20)}$

Chart 3. Analysis of references according to objectives and results, 1992-2011

\begin{tabular}{|c|c|c|}
\hline Reference & Objective & Results \\
\hline Post et al. ${ }^{(10)}$ & $\begin{array}{l}\text { To investigate possible prognostic factors for hospital mortality in } \\
\text { children under one year of age living in the metropolitan area of } \\
\text { Rio de Janeiro, who died between May } 1986 \text { and April 1987, with } \\
\text { diarrhea or pneumonia as the underlying cause of death. }\end{array}$ & $\begin{array}{l}\text { There was no association between breastfeeding and hospital mortality from diarrhea, } \\
\text { and breastfeeding frequencies up to } 1 \text { month of age were very similar between cases } \\
(60 \%) \text { and the control group (59\%). }\end{array}$ \\
\hline Bittencourt et al. ${ }^{(11)}$ & $\begin{array}{l}\text { To evaluate whether, during the first } 6 \text { months of life, there was a } \\
\text { differential effect of diarrhea upon the monthly weight and height } \\
\text { growth rates between breastfed children and fully weaned children. }\end{array}$ & $\begin{array}{c}\text { Weaned children showed delayed height and weight growth rates due to higher } \\
\text { incidence and higher prevalence of diarrhea. Breastfeeding effectively mitigates the } \\
\text { adverse effect of diarrhea upon monthly weight rates. }\end{array}$ \\
\hline Fuchs and Victoria ${ }^{(12)}$ & $\begin{array}{c}\text { To evaluate the effect of demographic, socioeconomic, } \\
\text { environmental, maternal reproductive, dietary and nutritional } \\
\text { variables upon the risk and prognosis of diarrhea, using } \\
\text { hierarchical analysis. }\end{array}$ & $\begin{array}{l}\text { Low birth weight, height-to-age deficit and lack of breastfeeding were risk and } \\
\text { prognostic factors for diarrhea. }\end{array}$ \\
\hline Barros et al. ${ }^{(13)}$ & $\begin{array}{l}\text { To evaluate the prevalence of breastfeeding, morbidity and the } \\
\text { nutritional status of a group of children, some of whom had } \\
\text { attended lactation centers and the others not. }\end{array}$ & $\begin{array}{l}\text { A greater proportion of children accompanied at lactation centers had been exclusively } \\
\text { breastfed; children who attended the lactation centers had less diarrhea in the two } \\
\text { weeks prior to the study than those who did not attend, and their weight was more } \\
\text { appropriate for age. }\end{array}$ \\
\hline Escuder et al..(14) & To study the impact of breastfeeding on death rate reduction. & $\begin{array}{c}\text { The preventable mortality fraction from respiratory infection varied between } \\
33 \text { and } 72 \% \text {, according to municipality and age group. For diarrhea, the variation } \\
\text { was between } 35 \text { and } 86 \% \text {. Breastfeeding in the first year of life may be the most } \\
\text { feasible strategy to reduce post-neonatal mortality beyond the levels already } \\
\text { achieved in the municipalities of São Paulo. }\end{array}$ \\
\hline Vieira et al..$^{(15)}$ & $\begin{array}{l}\text { To assess the protective effects of breastfeeding against } \\
\text { diarrhea in children under } 1 \text { year. }\end{array}$ & $\begin{array}{l}\text { The occurrence of diarrhea was high (11.6\%), more frequently after the age of } 6 \\
\text { months }(63.3 \%) \text {. Non-breastfed children younger than } 6 \text { months had a } 64.0 \% \\
(95 \% \mathrm{Cl} \text { : } 1.07-2.51) \text { greater chance for diarrhea }(p<0.02) \text { than breastfed children. } \\
\text { When compared to exclusively breastfed children, this chance increased to } 82.0 \% \\
(95 \% \mathrm{Cl}: 1.11-3.01) \text { among non-breastfed children. }\end{array}$ \\
\hline Vanderlei and Silva ${ }^{(16)}$ & $\begin{array}{c}\text { To assess the mothers' awareness about causes, signs of } \\
\text { dehydration and management of acute diarrhea, as well as the } \\
\text { occurrence of hospitalization for complications of this disease in } \\
\text { their children under two years. }\end{array}$ & $\begin{array}{l}\text { Association between hospitalization for acute diarrhea in children under } 2 \text { years and } \\
\text { precarious living conditions, lack of breastfeeding and malnutrition. }\end{array}$ \\
\hline
\end{tabular}


Continuation

Chart 3. Analysis of references according to objectives and results, 1992-2011

\begin{tabular}{|c|c|c|}
\hline Reference & Objective & Results \\
\hline Vitolo et al..$^{(17)}$ & $\begin{array}{l}\text { To assess the impact of the application of the nutritional guidelines } \\
\text { for children under } 2 \text { years of age established by the General } \\
\text { Coordination of Food and Nutrition Policy of the Ministry of Health, } \\
\text { through a randomized intervention study. }\end{array}$ & $\begin{array}{l}\text { The intervention was associated with a higher proportion of exclusive breastfeeding } \\
\text { at } 4 \text { months ( } \mathrm{RR}=1.58 ; 95 \% \mathrm{Cl}: 1.21-2.06) \text {, at } 6 \text { months ( } \mathrm{RR}=2.34 ; 95 \% \mathrm{Cl}: 1.37-3.99) \text {, } \\
\text { and breastfeeding at } 12 \text { months ( } \mathrm{RR}=1.26 ; 95 \% \mathrm{Cl}: 1.02-1.55) \text {; it was also associated } \\
\text { with a lower proportion of children with diarrhea ( } \mathrm{RR}=0.68 ; 95 \% \mathrm{Cl}: 0.51-0.90) \text {, respiratory } \\
\text { problems ( } \mathrm{RR}=0.63 ; 95 \% \mathrm{Cl}: 0.46-0.85 \text { ), medication use ( } \mathrm{RR}=0.56 ; 95 \% \mathrm{Cl}: 0.34-0.91 \text { ), } \\
\text { and dental caries ( } \mathrm{RR}=0.56 ; 95 \% \mathrm{Cl}: 0.32-0.96) \text { in the age group of } 12 \text { to } 16 \text { months. }\end{array}$ \\
\hline Brandão et al..(18) & $\begin{array}{l}\text { To describe the clinical and epidemiological characteristics of } \\
\text { children with acute diarrhea and shock admitted to the pediatric } \\
\text { intensive care unit, and compare the clinical outcomes between } \\
\text { death and survival groups, identifying factors associated with death. }\end{array}$ & $\begin{array}{l}\text { In } 53 / 61 \text { children, the duration of exclusive breastfeeding was less than three months, and } \\
\text { only } 8 / 61 \text { were breastfed at admission. No association was found between sex ( } p=0.78) \text {, } \\
\text { age ( } p=0.07 \text { ) and lactation ( } p=0.63 \text { ) and progression to death. Acute diarrhea with shock } \\
\text { preferably affects artificially fed young infants, with a high mortality rate. }\end{array}$ \\
\hline $\begin{array}{l}\text { Boccolini and } \\
\text { Boccollini(19) }^{(19)}\end{array}$ & $\begin{array}{l}\text { To evaluate the relation between breastfeeding and admissions for } \\
\text { diarrheal diseases in children aged under } 1 \text { year, in Brazilian capital } \\
\text { cities and the Federal District, in } 2008 .\end{array}$ & $\begin{array}{l}\text { In } 2008 \text {, both exclusive breastfeeding (tax rate }=0.76 ; 95 \% \mathrm{Cl}: 0.61-0.94 \text { ) and breastfeeding } \\
\text { in children up to } 9-12 \text { months of age (tax rate }=0.72 ; 95 \% \mathrm{Cl}: 0.52-0.99 \text { ) managed to reduce } \\
\text { hospitalization rates for diarrheal diseases in the studied population. }\end{array}$ \\
\hline Bernardi et al. ${ }^{(20)}$ & $\begin{array}{l}\text { To assess the impact of the program Ten steps to a healthy } \\
\text { diet: ood guide for children under } 2 \text { years of age upon } \\
\text { the duration of exclusive breastfeeding and to reduce the } \\
\text { occurrence of diarrhea and symptoms of respiratory morbidity } \\
\text { in children aged } 6 \text { to } 9 \text { months. }\end{array}$ & $\begin{array}{l}\text { A longer duration of exclusive breastfeeding age }(p=0.02) \text { was observed in the intervention } \\
\text { group, but no statistically significant changes were observed in the prevalence of diarrhea } \\
\text { and symptoms of respiratory morbidity. Further analysis showed that the duration of } \\
\text { exclusive breastfeeding was higher in the group of children with no occurrence of diarrhea } \\
\text { ( } p=0.001) \text { and without symptoms of respiratory morbidity ( } p=0.03) \text {. These results suggest } \\
\text { that the strategy was not enough to interfere in the occurrence of morbidities, but it was } \\
\text { effective in increasing exclusive breastfeeding time. }\end{array}$ \\
\hline
\end{tabular}

CI 95\%: confidence interval; RR: relative risk.

\section{DISCUSSION}

The main prognostic factors for hospital mortality are diarrhea and pneumonia. ${ }^{(10)}$ Diarrhea has different risk factors, which are interrelated and contribute to its aggravation, which leads to greater number of admissions. ${ }^{(14)}$ Hospitalization for acute diarrhea is associated with poor living conditions, lack of breastfeeding, malnutrition, lack of maternal knowledge about the correct handling of diarrheal episodes and the use of oral rehydration salts - suggesting that this lack of knowledge reflects the mothers' poverty, low schooling level, poor access to health services and social exclusion. ${ }^{(16)}$

However, there was a decrease in infant mortality rates in Brazil, due to greater access to better quality health services and sanitation. ${ }^{(14)}$ Nonetheless, there are different distributions of income among the various regions; consequently, living conditions are unequal, which can trigger high rates of diarrhea in children in some locations.

It is noteworthy that children exclusively breastfed for 6 months and breastfed for up to 12 months present lower hospitalization rates for diarrheal disease in hospitals of the Brazilian Public Health System (SUS, acronym in Portuguese), highlighting the role of this practice in reducing child mortality. ${ }^{(19)}$

The breastfeeding scholars presented in this study agreed that breast milk is endowed with properties that provide adequate child development and growth. Breastfeeding in the first year of life may be the most viable strategy for reducing post-neonatal mortality. ${ }^{(14)}$
Breastfeeding and exclusive breastfeeding protection against diarrhea was evident in children under 6 months. ${ }^{(15)}$ It was also observed that the majority of children hospitalized for acute diarrhea were receiving artificial feeding. ${ }^{(18)}$

Children who are breastfed up to 1 year are hospitalized less often from diarrhea. ${ }^{(19)}$ A systematic, consistent and dynamic structuring of breastfeeding promotion activities is needed in order to reduce early weaning, since breast milk has a protective effect against diarrhea. ${ }^{(11)}$

Several studies show that it is possible to improve breastfeeding rates with effective actions, such as early initiation of breastfeeding in maternity wards and training of healthcare professionals to provide breastfeeding counseling. ${ }^{(21)}$

Some health interventions should be taken to reduce infant mortality. Child feeding is one of them. The Ministry of Health prepared a food guide for children aged up to 2 years. Exclusive breastfeeding until 6 months and complementary feeding for children after this age are among the orientations outlined in the manual. ${ }^{(17)}$ In this study, the authors showed that mothers who received guidance on healthy eating habits breastfed longer as compared to those who did not. Therefore, education programs on infant feeding should be widely available, since this promotes positive changes in children eating habits and living conditions. ${ }^{(20)}$

Another strategy adopted in some cities was the creation of Lactation Centers to support mothers in 
breastfeeding. The proposed training and education of these mothers on management of breastfeeding was effective in increasing the duration of exclusive breastfeeding. ${ }^{(13)}$

Breastfeeding, despite being a biologically determined action, is subject to sociocultural factors, ${ }^{(22)}$ which influence the child's health, because longer breastfeeding allows better health conditions for children. ${ }^{(2)}$

According to the WHO and the UN Children's Fund (UNICEF), approximately 6 million children do not die each year due to exclusive breastfeeding. ${ }^{(21)}$ Breastfeeding promotion and encouragement strategies, as the Baby-Friendly Hospital Initiative, launched in 1992 by WHO/UNICEF, have increased the prevalence and duration of breastfeeding. ${ }^{(23)}$ In addition to this initiative, other breastfeeding promotion interventions can be developed by municipalities, aimed to increase breastfeeding duration, as prenatal, delivery and postpartum care educational actions. ${ }^{(24)}$

Breastfeeding depends on factors that may be related to the mother, such as age, schooling level ${ }^{(25)}$ and attitude towards breastfeeding, as well as factors related to the child and the environment, as the conditions of birth and the postpartum period, and there are also environmental factors, such as maternal work and daily living circumstances. ${ }^{(22)}$ Health services, economic conditions, the beliefs and the artificial milk industry appeal may also interfere with the breastfeeding process. ${ }^{(26)}$

Another issue to consider is the time when the child turns 6 months, and starts receiving complementary feeding, and may have difficulty in getting used to the new food, in addition to malabsorption of nutrients and metabolic changes, which, in turn, can contribute to the onset of diarrheal diseases. ${ }^{(27)}$

Lactation Centers and education programs on infant feeding are interventions that contribute to increase breastfeeding duration.

Diarrhea is a condition caused by many factors, and its prevention is related to social, economic and cultural aspects of the individual. Health care should focus on prevention, not just curative treatment. Public health policies should be directed to the context of each locality, to mitigate the problems that permeate early weaning.

\section{CONCLUSION}

The analyzed studies show breastfeeding as an important factor in prevention and protection against diarrhea in children under 2 years. The results suggest that this practice is important to reduce post-neonatal mortality and hospitalization rate due to diarrheal diseases in children.

\section{REFERENCES}

1. Catafesta F, Zagonel IP, Martins M, Venturi KK. A amamentação na transição puerperal: o desvelamento pelo método de pesquisa-cuidado. Esc Anna Nery Rev Enferm. 2009;13(3):609-16.

2. Stuebe A. The risks of not breastfeeding for mothers and infants. Rev Obstet Gynecol. 2009;2(4):222-31.

3. Brasil. Ministério da Saúde. Secretaria de Atenção à Saúde. Departamento de Ações Programáticas e Estratégicas. II Pesquisa de Prevalência de Aleitamento Materno nas Capitais Brasileiras e Distrito Federal. Brasília (DF): Ministério da Saúde; 2009.

4. Toma TS, Rea MF. Benefícios da amamentação para a saúde da mulher e da criança: um ensaio sobre as evidências. Cad Saude Publica. 2008;24 Suppl 2:5235-46. Review.

5. Barros V0, Cardoso MA, Carvalho DF, Gomes MM, Ferraz NV, Medeiros CC. Aleitamento materno e fatores associados ao desmame precoce em crianças atendidas no programa de saúde da família. Nutrire Rev Soc Bras Aliment Nutr. 2009;34(2):101-14

6. Bernardi JL, Jordão RE, Barros Filho AA. [Supplementary feeding of infants in a developed city within the context of a developing country]. Rev Panam Salud Publica. 2009;26(5):405-11. Portuguese.

7. Brasil. Ministério da Saúde. Secretaria de Atenção à Saúde. Departamento de Atenção Básica. Saúde da criança: nutrição infantil: aleitamento materno e alimentação complementar. Brasília (DF): Ministério da Saúde; 2009. ( série A. Normas e manuais técnicos. Cadernos de Atenção Básica, n.23).

8. Brasil. Departamento de vigilância Epidemiologica. Informe técnico. Doença diarréica por rotavírus: vigilância epidemiológica e prevenção pela vacina oral de rotavírus humano - VORH. Versão preliminar. Brasília (DF): Departamento de Vigilância Epidemiológica; 2005.

9. Pereira IV, Cabral IV. Diarréia aguda em crianças menores de um ano: subsídios para o delineamento do cuidar. Esc Anna Nery Rev Enferm. 2008; 12(2):224-9.

10. Post CL, Victora CG, Valente JG, Leal Mdo C, Niobey FM, Sabroza PC. Fatores prognósticos de letalidade hospitalar por diarreia ou pneumonia em menores de um ano de idade. Estudo de caso e controle. Rev Saude Publica. 1992;26(6):369-78

11. Bittencourt SA, Leal Mdo C, Jordan-Gadelha AM, Oliveira MA. Crescimento, diarreia e aleitamento materno: 0 caso da Vila do João. Cad Saude Publica. 1993;9 Suppl 1:7-13

12. Fuchs SC, Victora CG. Fatores de risco e prognósticos para diarreia entre crianças brasileiras: uma aplicação especial do delineamento de casos e controles. Cad Saude Publica. 2002;18(3):773-82.

13. Barros FC, Semer TC, Tonioli Filho S, Victora CG. Avaliação do impacto de Centros de Lactação sobre padrões de amamentação, morbidade e situação nutricional: um estudo de coorte. Rev Bras Epidemiol. 2002;5(1):5-14.

14. Escuder MM, Venancio SI, Pereira JC. Estimativa de impacto da amamentação sobre a mortalidade infantil. Rev Saude Publica. 2003;37(3):319-25.

15. Vieira GO, Silva LR, de 0 Vieira T. Alimentação infantil e morbidade por diarréia. J Pediatr (Rio J). 2003;79(5):449-54.

16. Vanderlei LC, Silva GA. Diarréia aguda: o conhecimento materno sobre a doença reduz o número de hospitalizações nos menores de dois anos. Rev Assoc Med Bras. 2004;50(3):276-81.

17. Vitolo MR, Bortolini GA, Feldens CA, Drachler Mde L. Impactos da implementação dos dez passos da alimentação saudável para crianças: ensaio de campo randomizado. Cad Saude Publica. 2005;21 (5):1448-57.

18. Brandão MB, Lopes CE, Morcillo AM, Baracat EC. 0 óbito em crianças com diarreia aguda e choque em UTI. Rev Assoc Med Bras. 2005;51(4):237-40.

19. Boccolini CS, Boccollini PM. Relação entre aleitamento materno e internações por doenças diarreicas nas crianças com menos de um ano de vida nas capitais brasileiras e Distrito Federal, 2008. Epidemiol Serv Saude. 2011;20(1):19-26.

20. Bernardi JR, Gama CM, Vitolo MR. Impacto de um programa de atualização em alimentação infantil em unidades de saúde na prática do aleitamento materno e na ocorrência de morbidade. Cad Saude Publica. 2011;27(6):1213-22. Portuguese. 
21. United Nations Children's Fund (UNICEF). Tracking progress on child and maternal nutrition: a survival and development priority [Internet]. UNICEF. New York; 2009 [cited 2014 Feb 22]. Available from: http://www.unicef.pt/ docs/Progress on Child and Maternal Nutrition EN 110309.pdf

22. Caminha Mde F, Serva VB, dos Anjos MM, Brito RB, Lins MM, Batista-Filho M. Aleitamento materno exclusivo entre profissionais de um Programa Saúde da Família. Cien Saude Colet. 2011;16(4):2245-50.

23. Brasil. Ministério da Saúde. Departamento de Ações Programáticas e Estratégicas. Pesquisa de prevalência de aleitamento materno em municípios brasileiros. Brasília (DF); Ministério da Saúde: 2010.

24. Brasil. Ministério da Saúde. Secretaria de Atenção à Saúde. Área Técnica de Saúde da Criança e Aleitamento Materno. Rede Amamenta Brasil: os primeiros passos (2007-2010). Brasília (DF): Ministério da Saúde; 2011. Série I. História da Saúde.

25. Caminha Mde F, Batista Filho M, Serva VB, Arruda IK, Figueiroa JN, Lira PI. Time trends and factors associated with breastfeeding in the state of Pernambuco, Northeastern Brazil. Rev Saude Publica. 2010;44(2):240-8.

26. Martins CC, Vieira GO, Vieira TO, Mendes CM. Fatores de riscos maternos e de assistência ao parto para interrupção precoce do aleitamento materno exclusivo: estudo de coorte. Rev Baiana Saude Publica. 2011;35 Suppl1:167-78.

27. Barreto MS, Silva RL, Marcon SS. Morbidity in children of less than one year of age in risky conditions: a prospective study. Online Braz J Nurs. 2013; 12(1):5-20. 